Sains Malaysiana 46(9)(2017): 1441-1447

http://dx.doi.org/10.17576/jsm-2017-4609-12

\title{
Carbon Content in Different Seagrass Species in Andaman Coast of Thailand
} (Kandungan Karbon dalam Pelbagai Spesies Rumpai Laut di Teluk Andaman, Thailand)

\author{
Milica StankoviC*, JANMANEE PANYAWAi, KAMARUdin JANSANIT, TIPAMAT UPANOI \& ANCHANA PRATHEP
}

\begin{abstract}
Seagrass meadows have one of the highest carbon sequestration and storage capacities than any other ecosystems. Carbon that is stored in the ecosystem is accumulated in the deposited sediment as well as in the living, above and below ground biomass, with a different rate of carbon sequestration and storage between the species. The objective of this research was to investigate carbon storage in the living plants and in the sediment among species of different size in tropical waters. The samples were collected from Phuket province, Thailand, in the high density monospecific patches of different size species (Enhalus acoroides as a big. Thalassia hemprhicii as a medium and Halophila ovalis as a small size species). Total carbon and carbon stored in above and below ground, was significantly different between the species $(\mathrm{p}<0.05)$, with the highest values in below ground parts of $\mathrm{E}$. acoroides and T. hemprichii $238.10 \pm 85.07$ and $134 \pm 21.55 \mathrm{~g} \mathrm{Dw}$ $m^{-2}$, respectively. Average organic carbon in the sediment was significantly different $(\mathrm{p}<0.05)$ as well, with $\mathrm{E}$. acoroides having highest organic carbon content in the deeper layers of the sediment $1.14 \pm 0.25 \% C_{\text {org }}$, while the other two species had higher organic carbon in the top and medium layers of sediment. The results of this preliminary research propose that big size species have higher carbon content than smaller species, which reflects in higher sequestration rates of carbon from the ocean, thus reducing the ocean carbon budget. Moreover, it provides necessary information on size of the species which is the key for the future carbon storage studies in the region.
\end{abstract}

Keywords: Above ground; below ground; organic carbon; seagrass; sediment

\section{ABSTRAK}

Padang rumpai laut mempunyai keupayaan menyerap karbon dan kapasiti simpanan antara yang tertinggi berbanding ekosistem yang lain. Karbon yang disimpan di dalam ekosistem yang terkumpul di dalam sedimen didepositkan di dalam kehidupan, atas dan bawah tanah biojisim, dengan kadar penyerapan dan simpanan karbon yang berbeza antara spesies. Kajian ini bertujuan untuk mengkaji penyimpanan karbon dalam tumbuh-tumbuhan dan sedimen antara spesies berbeza saiz di perairan tropika. Sampel kajian telah dikumpul dari daerah Phuket, Thailand, dalam tompok monospesifik berkepadatan tinggi spesies dengan saiz yang berbeza (Enhalus acoroides Thalassia hemprhicii yang besar, sebagai medium serta Halophila ovalis sebagai satu spesies saiz kecil). Jumlah karbon dan karbon yang disimpan di atas dan bawah tanah, adalah berbeza antara spesies ( $\mathrm{p}<0.05)$, dengan nilai tertinggi di bawah bahagian tanah $\mathrm{E}$. acoroides dan

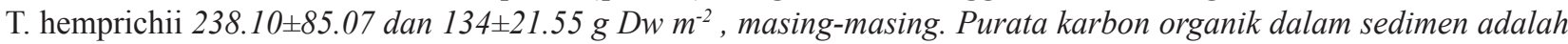
berbeza secara signifikan $(\mathrm{p}<0.05)$ dengan E. acoroides mempunyai karbon organik yang tertinggi di lapisan sedimen lebih dalam 1.14 $0.25 \%$ Corg, manakala kedua-dua spesies lain mempunyai karbon organikyang lebih tinggi di lapisan atas dan sederhana enapan. Hasil kajian awal ini mencadangkan bahawa spesies saiz besar mempunyai kandungan karbon lebih tinggi daripada spesies yang lebih kecil, yang mencerminkan meningkatnya kadar penyerapan karbon dari laut, dengan itu mengurangkan bajet karbon lautan. Selain itu, ia menyediakan maklumat yang diperlukan mengenai saiz spesies yang merupakan kunci bagi kajian menyimpan karbon pada masa hadapan di rantau ini.

Kata kunci: Atas permukaan tanah; bawah permukaan tanah; enapan; karbon organik; rumpai laut

\section{INTRODUCTION}

Seagrass species are one of the highest productive ecosystems of the world with the global net productivity of $400 \mathrm{Tg} / \mathrm{yr}$ (Duarte et al. 2005). Most of their primary production $(80 \%)$ is not consumed (Duarte et al. 2013) but it is exported to adjacent ecosystems, (24\%; Duarte \& Cebrian 1996) or it is buried in the sediment (30-50\%; Duarte et al. 2005). The estimated carbon burial in the seagrass meadows is 48.0-112 Tg per year (Duarte et al. 2013), while the total ocean carbon burial is $243.6 \mathrm{Tg} /$ yr (Duarte et al. 2005). With these rates of carbon burial seagrass meadows are responsible for $50 \%$ of the global carbon sequestration in the marine sediment despite occupying $0.2 \%$ of the ocean surface (Duarte et al. 2013). These ecosystems act as a carbon sink (Duarte et al. 2005; Mcleod et al. 2011), where carbon can be trapped for a long period of time (centuries and millennia) (Duarte et al. 2005; Macreadie et al. 2014; Rozaimi et al. 2016), hence contributing the mitigation of anthropogenic $\mathrm{CO}_{2}$ emissions (Fourqurean et al. 2012a). The destruction and/or 
loss of the vegetation triggers many negative effects on the ecosystem, of which the important one is erosion of already trapped carbon and lack of carbon sequestration ability (Marbà et al. 2015). One possible pathway of liberated carbon is to exit water column and pass into the atmosphere and to contribute to the atmospheric $\mathrm{CO}_{2}$ (Macreadie et al. 2014), increasing the atmospheric carbon budget.

The ability of carbon sequestration of the seagrasses lies in their high productivity, canopy structure as well as lower nitrogen and phosphorus content in tissues and low concentrations of the oxygen in the sediment, ensuring low decomposition rates and incomplete remineralization (Duarte et al. 1998). The high below ground production have direct influence on the carbon sequestration, as more than $70 \%$ of carbon is contributed to the total carbon stock (Supriadi et al. 2014) and $45 \%$ of total rhizome production is directly placed in the sediments (Duarte et al. 1998). The seagrass species of South-east Asia have various ranges of sizes, from small Halophila ovalis to the largest seagrass species Enhalus acoroides (Duarte 1991). Their difference in the size, growth, productivity of leaves, roots and rhizomes (Duarte et al. 2010, 1998; Vermaat et al. 1995), as well as the age of the shoots (Vermaat et al. $1995)$ influence the rate of the carbon storage.

The aim of this study was to investigate carbon content in living parts as well as in the sediment among the species of different size in a healthy seagrass meadow.

\section{MATERIALS AND METHODS}

\section{STUDY SITE}

The research was conducted in Phuket province at $\mathrm{Pa}$ Khlok Bay in 2015. Pa Khlok Bay is located on Phuket Island (Figure 1) and it has one of the largest seagrass meadows in the province. The seagrass meadow covers an area of 284.8 hectare, with a rich diversity and high density throughout the meadow, good indicator of a healthy seagrass meadow. The samples were collected during summer period in March of 2015.

\section{SAMPLING AND LABORATORY ANALYSIS}

Three monospecific seagrass patches were located, Enhalus acoroides as a large species patch, Thalassia hemprichii as a medium size and Halophila ovalis as a small size species patch. These three species were selected as the good

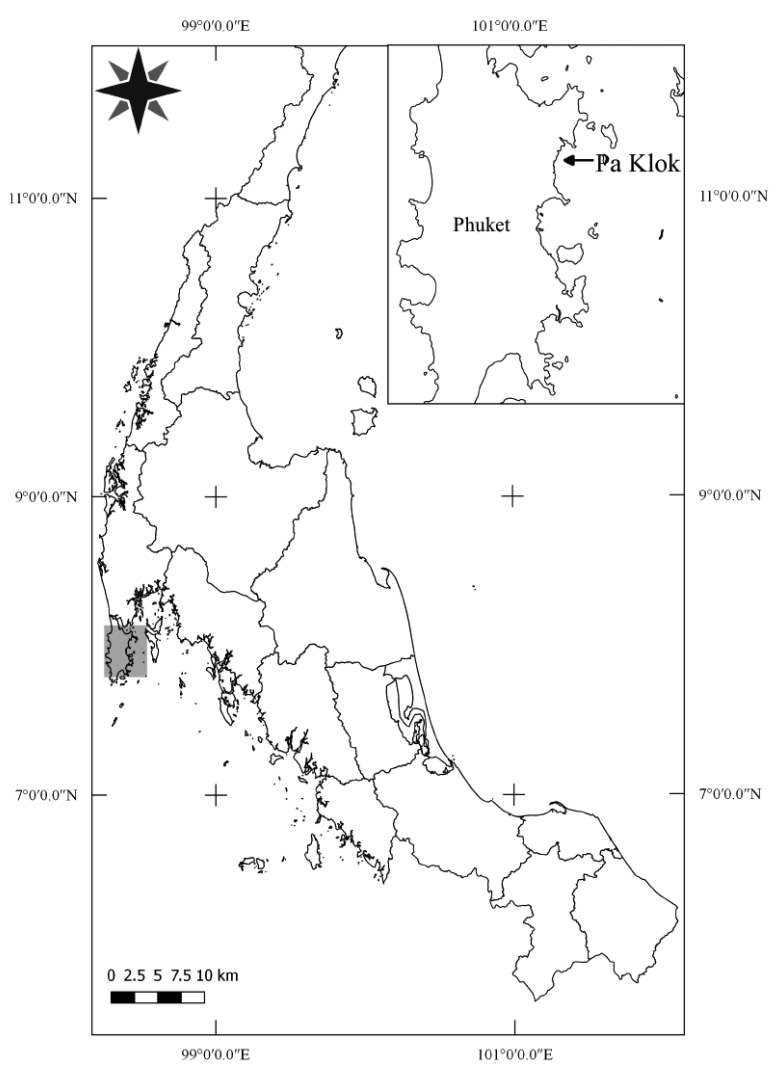

FIGURE 1. Map of the study area

representatives of three size groups (Table 1). Distance among the patches was at least $100 \mathrm{~m}$ and 4 replications of biomass and one replication of sediment samples were collected per patch.

Biomass was collected from $50 \times 50 \mathrm{~cm}^{2}$ quadrats, which were randomly placed in the high density areas of each patch (50-75\%). All the living vegetation from a quadrat was collected and placed in bags. In the laboratory, samples from each species were separated into above (leaves) and below ground (roots and rhizomes) parts, leaf blades were manually scraped to remove epiphytes and cleaned material was dried in the oven on $60^{\circ} \mathrm{C}$ until it reached constant weight. The dry weight of the above and below ground parts was recorded and total biomass for each species was calculated as well as for each vegetative part. Small subsamples were crushed into powder and 20 mg of subsamples were sent for percentage of organic carbon analysis to Laboratory of Forest Soils, Department

TABLE 1. Size comparison of three seagrass species

\begin{tabular}{lcccc}
\hline \multirow{2}{*}{ Species } & \multicolumn{2}{c}{ Diameter of below ground $(\mathrm{mm})$} & \multicolumn{2}{c}{ Leaf size $(\mathrm{mm})$} \\
\cline { 2 - 5 } & Rhizome & Root & Length & Width \\
\hline Enhalus acoroides & $13.2^{\mathrm{a}}$ & $3.5^{\mathrm{a}}$ & $500.8 \pm 1.82^{\mathrm{b}}$ & $15.7 \pm 0.04^{\mathrm{b}}$ \\
Thalassia hemprichii & $3.43^{\mathrm{a}}$ & $1.7^{\mathrm{a}}$ & $86.8 \pm 0.53^{\mathrm{b}}$ & $8 \pm 0.04^{\mathrm{b}}$ \\
Halophila ovalis & $1.09^{\mathrm{a}}$ & $0.57^{\mathrm{a}}$ & $15.4 \pm 0.09^{\mathrm{b}}$ & $8.5 \pm 0.08^{\mathrm{b}}$ \\
\hline
\end{tabular}

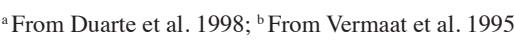


of Silvaculture, Faculty of Forestry, Kasetsart University, Bangkok. Carbon content for above and below ground parts for each species was calculated as in (1):

$$
\text { Carbon content }(\mathrm{mg})=\begin{aligned}
& \text { Carbon }(\%) * \text { weight of } \\
& \text { the sample }(\mathrm{mg})
\end{aligned}
$$

The carbon stored in the sediment was estimated by extracting the sediment using stainless steel cores. There was one sample set of the sediment collection per species meadow in high density areas (same percentage as for biomass sampling), as this was preliminary study. The core had diameter of $5 \mathrm{~cm}$ and along $1 \mathrm{~m}$ length core a strip of 3 $\mathrm{cm}$ width was drilled in order to ease subsample collection. The strip was covered with duct tape during the sampling, so leakage thorough the strip and oxygen intrusion was limited. Immediately after the core was pulled from the bed, sediment top and bottom parts were covered to limit oxygen intrusion in the deepest parts of the sediment. The subsamples were taken at the interval of $3 \mathrm{~cm}$ (Fourqurean et al. $2012 \mathrm{~b}$ ) by cutting the duct tape from top to bottom in the cores with a minimal compaction. Each subsample was packed in pre-labeled bags and kept at $4^{\circ} \mathrm{C}$ from $24 \mathrm{~h}$ of collection. In the laboratory, samples were dried in the oven on $60^{\circ} \mathrm{C}$ until constant weight. In order to correct the core compression, compaction correction factor was calculated for each species (2) and the depth of the samples was then rescaled:

$$
\begin{aligned}
\text { Correction factor }= & \text { Length of the recovered } \\
& \text { sample }(\mathrm{cm}) / \text { depth that core } \\
& \text { reached }(\mathrm{cm})
\end{aligned}
$$

For further analysis of the organic carbon content, each subsample $\sim 5$ grams were ground into powder and $20 \mathrm{mg}$ of the grounded subsamples were sent for total carbon analysis in Bangkok. From the rest of the ground samples, 1-2 grams were used for analysis of inorganic carbon by acidification with $1 \mathrm{~N}$ hydrochloric acid $(\mathrm{HCl})$ and inorganic content of the sample was calculated (3):

$$
\begin{array}{ll}
\text { Inorganic } \\
\text { carbon }(\%)=\begin{array}{l}
((\text { Dry mass before acid }(\mathrm{mg})- \\
\text { dry mass after acid } \left.(\mathrm{mg}))^{*} 0.12^{1}\right) / \\
\text { dry mass before acid }(\mathrm{mg})) * 100
\end{array}
\end{array}
$$

${ }^{1}=$ weight of the carbon in molecular calcium carbonate

Organic carbon in the subsamples was calculated as a difference of values of total and inorganic carbon. As the species have different root penetration depth in the sediment, the samples of the organic carbon in sediment were grouped into the three layers: top $(<10 \mathrm{~cm})$, medium $(11-40 \mathrm{~cm})$ and bottom layer $(>41 \mathrm{~cm})$.

\section{STATISTICAL ANALYSIS}

As all biomass, carbon in living parts and sediment samples didn't meet the assumptions of normality, non-parametric analysis was employed, Kruskal-Wallis analysis of variance and Wilcoxon sign-ranked test (R Studio 2015). In order to better understand the relationship between organic carbon and biomass, linear regression analysis was done (R Studio 2015).

\section{RESULTS AND DISCUSSION}

\section{BIOMASS AND CARBON STORAGE IN THE LIVING PARTS}

Total biomass highly varied among species $(p<0.05$, Table 2, Figure 2(a)) with the highest values in E. acoroides species of $167.1 \pm 57.35$ gram of dry weight per meter squared $\left(\mathrm{g} \mathrm{Dw}^{-2}\right)$, followed by $T$. hemprichii and $H$. ovalis (Table 2). The same pattern as biomass, was recorded in each living vegetative part of the plant (above and below ground), with significant difference among all the species $(p<0.05$, Table 2$)$ and higher values of biomass in below ground part than in above ground part (Figure 2(b)). The highest biomass of above and below ground parts was found in the bigger species E. acoroides with $97.68 \pm 37.87 \mathrm{~g} \mathrm{Dw} \mathrm{m}^{-2}$ for above and $238.1 \pm 85.07 \mathrm{~g}$ Dw $\mathrm{m}^{-2}$ for below ground, following by T. hemprichii and H. ovalis (Table 1). The average above ground biomass measured in this study was much higher than reported by Duarte and Chiscano (1999), while average below ground biomass was higher than reported by Vermaat et al. (1995) and less than stated by Duarte and Chiscano (1999). In our study as well as in Poovachiranon and Chasang (1994), Prathep et al. (2010), Rattanachot and Prathep (2015) and Vichkovitten (1998), below ground biomass exceeded above ground biomass, especially in E. acoroides and T. hemprichii. High biomass of these two species suggest bigger values of the excess biomass and larger $\mathrm{CO}_{2}$ sinks, as threshold of excess $41 \mathrm{~g} \mathrm{Dw}$ $\mathrm{m}^{-2}$ is necessary for a meadow to acts as a net $\mathrm{CO}_{2}$ sink (Duarte et al. 2010). On the other hand, in our study $H$. ovalis had slightly higher below ground biomass than biomass above ground, while in the study of Duarte and Chiscano (1999) and Prathep (2012) had much higher above ground biomass than below ground. This might be due to specificity of $H$. ovalis roots which are very thin, but they branch to increase the surface, thus increasing below ground biomass (Duarte et al. 1998). The difference in the biomass between the species supports the roles of the species in the ecosystem. Smaller species support high grazing pressure and need to be able to transfer their production to the food webs, fast growing vegetation parts of $H$. ovalis, $2.10 \pm 0.10$ days per leaf pair and rhizome elongation rate of $9.06 \pm 1.02 \mathrm{~mm}$ per day (Kaewsrikhaw et al. 2016) are capable to colonize new areas in a short period of time. On the contrary, the bigger species are considered more constant species, with longer life span, low mortality rates and long lived shoots (Vermaat et al. 1995). This allows them to allocate their production into below ground and contribute more than $70 \%$ of total carbon stock (Supriadi et al. 2014). 

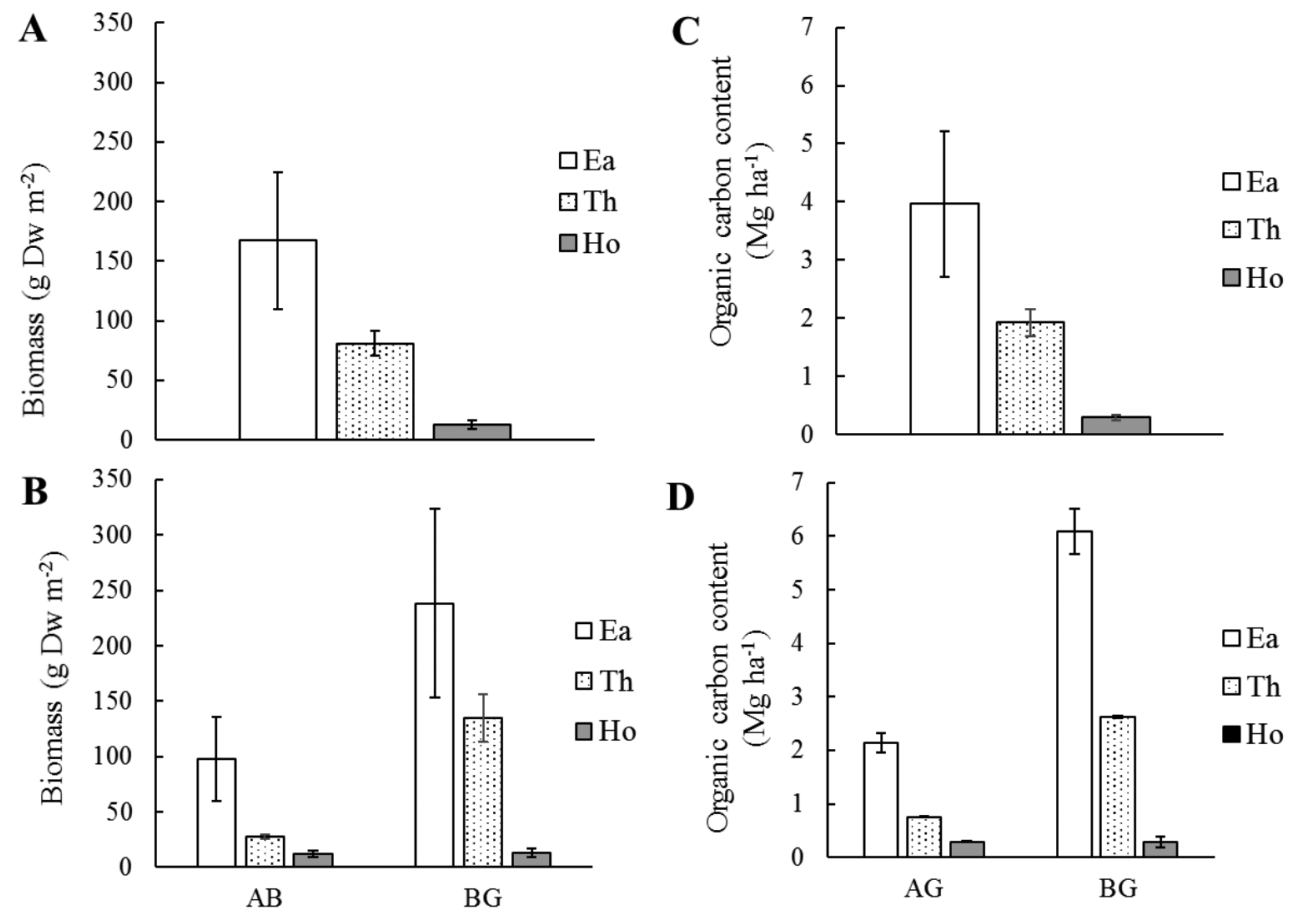

FIGURE 2. A-B: Biomass ( $\mathrm{g}$ Dw m $\left.\mathrm{m}^{-2}\right)$ and C-D: organic carbon content $\left(\mathrm{Mg} \mathrm{ha}^{-1}\right)$ of all seagrass species ${ }^{\mathrm{a}}$ and their living parts ${ }^{\mathrm{b}}$

${ }^{\mathrm{a}} \mathrm{Ea}$ - Enhalus acoroides, Th - Thalassia hemprichii, Ho - Halophila ovalis. ${ }^{\mathrm{b}} \mathrm{AB}$ - above ground biomass, $\mathrm{BG}$ - below ground biomass

TABLE 2. Average of biomass and carbon content in vegetative parts of three different seagrass species. The values with the same letter in the same column do not differ significantly $(p<0.05)$

\begin{tabular}{lcccccc}
\hline \multirow{2}{*}{ Species } & \multicolumn{3}{c}{ Biomass $\left(\mathrm{g} \mathrm{Dw} \mathrm{m}^{-1}\right)$} & \multicolumn{3}{c}{ Carbon content $\left.(\mathrm{Mg} \mathrm{ha})^{-1}\right)$} \\
\cline { 2 - 7 } & Total & Above ground & Below ground & Total & Above ground & Below ground \\
\hline Enhalus acoroides & $167.105 \pm 57.35^{\mathrm{A}}$ & $97.68 \pm 37.87^{\mathrm{A}}$ & $238.10 \pm 85.07^{\mathrm{A}}$ & $8.15 \pm 2.5^{\mathrm{A}}$ & $3.13 \pm 0.8^{\mathrm{A}}$ & $6 \pm 1.93^{\mathrm{A}}$ \\
Thalassia hemprichii & $81 \pm 10.59^{\mathrm{A}}$ & $27.17 \pm 1.95^{\mathrm{B}}$ & $134 \pm 21.55^{\mathrm{B}}$ & $3.37 \pm 0.29^{\mathrm{B}}$ & $0.76 \pm 0.06^{\mathrm{B}}$ & $2.61 \pm 0.29^{\mathrm{B}}$ \\
Halophila ovalis & $12.62 \pm 3.35^{\mathrm{B}}$ & $11.76 \pm 2.85^{\mathrm{C}}$ & $13.48 \pm 3.92^{\mathrm{C}}$ & $0.56 \pm 0.09^{\mathrm{C}}$ & $0.28 \pm 0.05^{\mathrm{C}}$ & $0.28 \pm 0.05^{\mathrm{C}}$ \\
\hline
\end{tabular}

Total organic carbon content highly varied (Figure 2(c)), with significant difference $(p<0.05$, Table 2$)$ between the species, where highest values were recorded in the bigger species and lowest values in the smaller species of $3.97 \pm 1.25$ mega gram of carbon per hectare $\left(\mathrm{MgC} \mathrm{ha}^{-1}\right)$ in E. acoroides, followed by $T$. hemprichii and H. ovalis (Table 2). The bigger and medium size species had higher carbon content in the below ground, while smaller size species had higher carbon content in the above ground parts (Figure 2(d)). Carbon content in above as well as in below ground parts varied significantly between the species $(p<0.05$, Table 2$)$. The highest organic carbon content was recorded in E.acoroides, following by $T$. hemprichii and $H$. ovalis (Table 1$)$. The average worldwide organic carbon content of the living seagrass biomass is $2.52 \pm 0.48 \mathrm{Mg} \mathrm{Cha}^{-1}$ (Fourqurean et al. 2012 b), wherein the results of our study suggest 3.2 and 1.3fold increase for bigger seagrass and medium size species, 4.5-fold decrease for small size species. In Southeast Asian region, our study suggested much higher carbon content in the above and below ground parts than reported by Phang et al. (2015) and Prathep (2012), while Supriadi et al. (2014) reported much higher values. The variations of the carbon pool are based on the species size, as the bigger species have longer-lived vegetation parts and lower leaf production rates. The shoots of E. acoroides and T. hemprichii live longer, with average age of $787 \pm 125$ and $668 \pm 27$ days, than the H. ovalis shoots, $27 \pm 4.2$ days (Vermaat et al. 1995). Their older age increases the rate of the carbon sequestration and accumulation per day. The high leaf production rates of H. ovalis, $2.10 \pm 0.10$ days per leaf pair (Kaewsrikhaw et al. 2016), allows this species to grow much faster, which in turn decreases the ability of this species to, accumulate carbon. On the other hand, bigger and medium size species have fewer shoots production, $3.86 \pm 0.02$ leaves shoot $^{-1}$ per year for E. acoroides (Rattanachot \& Prathep 2011), which allows them to occupy the space more permanently and to retain resources for extended periods of time (Vermaat et al. 1995).

The results of the performed linear regression analysis of all three seagrass species showed significant relationship 
between biomass and organic carbon content (Figure 3; F $(1,22)=947.6, p=2.2 \mathrm{e}-16$ and $\left.\mathrm{R}^{2}=0.9763\right)$. Based on the results, organic carbon in the living parts of the plants can be successfully ( $>95 \%$ ) predicted from the biomass of the species, following the equation $\mathrm{y}=0.02390662 * \mathrm{x}$ 0.06894006 ( $\mathrm{x}=$ biomass of the species and $\mathrm{y}=$ carbon content). The given equation suggests that for every additional value of biomass we can expect organic carbon to increase by an average of 0.02390662 .

\section{ORGANIC CARBON IN THE SEDIMENT}

The average organic carbon in the sediment was significantly different $(p<0.05$, Table 3$)$ among the species, as it was expected. The highest average organic carbon was recorded in the E. acoroides of $0.72 \pm 0.37 \%$ $\mathrm{C}_{\text {org }}$, following with $T$. hemprichii and H. ovalis, (Table $3)$, respectively. In the top layer of sediment there was no significant difference among the species $(p>0.05$, Table 3 ), with the same average carbon in biggest species and the smallest species (Table 3). In the medium layer, there was high difference among the species ( $p<0.05$, Table 3$)$, with highest values in T. hemprichii of $0.91 \pm 0.31 \% \mathrm{C}_{\text {org }}$, followed by $E$. acoroides, and $H$. ovalis. In the bottom layer of the sediment significant difference among the species was displayed ( $p<0.05$, Table 3 ) with E. acoroides having the highest value of carbon content $1.14 \pm 0.25 \%$ $\mathrm{C}_{\text {org }}$, followed by almost equal values of organic carbon for T. hemprichii and H. ovalis, (Table 3). The bigger species E. acoroides expressed constant increase along the depth layers (Figure 4), while medium and small size species had different patterns. Thalassia hemprichii increases in carbon content in the top and medium layers, while in the bottom layer there was decline (Figure 4). The smaller species, $H$. ovalis, showed almost constant pattern of carbon content in the top and medium layers, with a small increase in the bottom layer of sediment (Figure 4). Our results reported much lower organic carbon (\%) than the study of Prathep (2012) and higher values than the study by Rattanachot and Prathep (2015) in Thailand and lower values reported in Singapore by Phang et al. (2015). The results from the organic carbon in the sediment suggested that bigger species such as E. acoroides store more carbon than the smaller and medium size species. Their underground living parts (roots and rhizomes) are bigger, thicker, robust and penetrate in much deeper layers of the sediment up to 1 m depth (Marbà et al. 2010), while smaller and medium size species underground parts are restricted to top and medium layer of the sediment (Marbà et al. 2010). The carbon content of $E$. acoroides was the highest among the species and as well it was increasing in each depth layer, while in the medium and small size species had opposite trend with a decrease in the bottom sediment layer. This suggest that bigger species have better ability to store carbon in deeper layers of the sediment than the medium and smaller size species where most of the organic rich soils in the seagrass meadows are found (Pendleton et al. 2012). Thalassia hemprichii had also very high carbon storage in the upper and medium layers of the sediment, where the plant's underground parts were able to penetrate in the sediment, up to $30-40 \mathrm{~cm}$ depth (Marbà et al. 2010). On the other hand, roots of the smaller seagrass

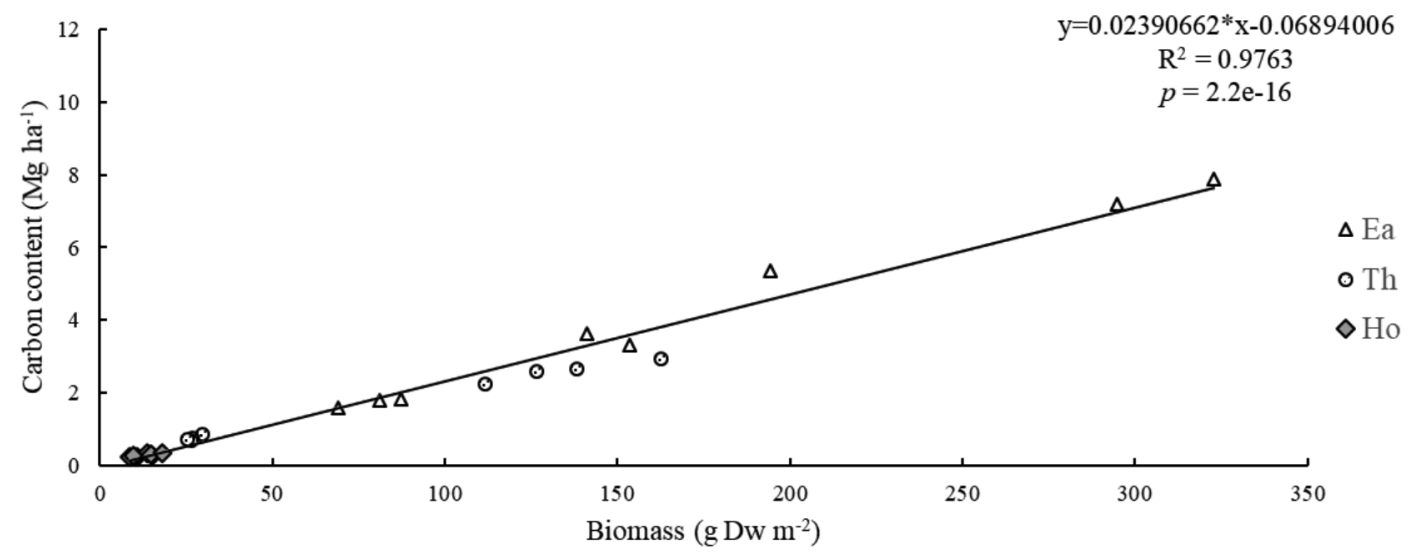

FIGURE 3. Linear regression of biomass of all three species ${ }^{\mathrm{a}}$ and organic carbon content

${ }^{\mathrm{a}} \mathrm{Ea}$ - Enhalus acoroides, Th - Thalassia hemprichii and Ho - Halophila ovalis

TABLE 3. Average organic carbon (\%) in sediment layers of three different seagrass species. The values with the same letter in the same column do not differ significantly $(p<0.05)$

\begin{tabular}{lcccc}
\hline Species & Total & Top layer & Medium layer & Bottom layer \\
\hline Enchalus acoroides & $0.72 \pm 0.37^{\mathrm{A}}$ & $0.29 \pm 0.05^{\mathrm{A}}$ & $0.58 \pm 0.16^{\mathrm{A}}$ & $1.14 \pm 0.25^{\mathrm{A}}$ \\
Thalassia hemprichii & $0.70 \pm 0.5^{\mathrm{A}}$ & $0.56 \pm 0.05^{\mathrm{B}}$ & $0.91 \pm 0.31^{\mathrm{B}}$ & $0.68 \pm 0.63^{\mathrm{B}}$ \\
Halophila ovalis & $0.43 \pm 0.21^{\mathrm{B}}$ & $0.29 \pm 0.04^{\mathrm{A}}$ & $0.34 \pm 0.06^{\mathrm{C}}$ & $0.52 \pm 0.27^{\mathrm{B}}$ \\
\hline
\end{tabular}




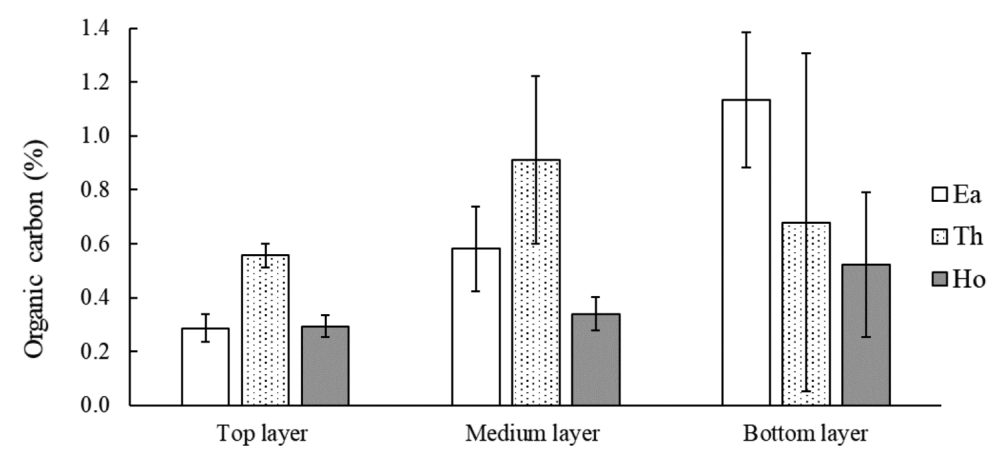

FIGURE 4. Average carbon content per sample for all three species ${ }^{\mathrm{a}}$ in different depth layers

a.Ea-Enhalus acoroides, Th-Thalassia hemprichii, Ho-Halophila ovalis

species $H$. ovalis, could penetrate only in the first few $\mathrm{cm}$ of the top sediment layer, up to 5-7 $\mathrm{cm}$ depth (Marbà et al. 2010), which is highly influenced by the wave action and is considered short term carbon pool. Also the roots of the H. ovalis have less fibrous tissues therefore they decompose faster (Duarte et al. 1998). The high carbon content of the sediment in this species patch could be from algal production or from terrestrial inputs as this species occupies depositional environments (Lavery et al. 2013).

\section{CONCLUSION}

These preliminary results suggested that bigger size species have better ability to store carbon in the plants as well as in the sediment. It also proposed the positive relationship between biomass and organic carbon in the plants. However, more studies are necessary to distinguish if this relationship is species specific.

\section{ACKNOWLEDGEMENTS}

This research was supported by the Higher Education Research Promotion and the Thailand's Education Hub for Southern Region of ASEAN Countries Project Office of the Higher Education Commission and the Graduate School of Prince of Songkla University. Special gratitude to the Seaweed and Seagrass Research Unit team at Prince of Songkla University, all the stuff at the Phuket Marine Biological Center, Phuket and Mr. Dejan Davidovic for their great assistance, especially on the fieldwork. The authors are also very grateful to the Laboratory of Forest Soils, Department of Silvaculture, Faculty of Forestry, Kasetsart University, Bangkok.

\section{REFERENCES}

Duarte, C.M. \& Chiscano, C.L. 1999. Seagrass biomass and production: A reassessment. Aquatic Botany 65(1-4): 159174.

Duarte, C.M. \& Cebrian, J. 1996. The fate of marine autotropic production. Limnology and Oceanography 41(18): 17581788.

Duarte, C.M. 1991. Seagrass depth limits. Aquatic Botany 40: 363-377.
Duarte, C.M., Losada, I.M., Hendriks, I.E., Mazarrasa, I. \& Marbà, N. 2013. The role of coastal plant communities for climate change mitigation and adaptation. Nature Climate Change 3: 961-968.

Duarte, C.M., Marbà, N., Gacia, E. \& Fourqurean, J.W. 2010. Seagrass community metabolism: Assessing the carbon sink capacity. Global Biogeochemical Cycles 24(4): GB4032. DOI. 10.1029/2010GB003793.

Duarte, C.M., Middelburg, J.J. \& Caraco, N. 2005. Major role of marine vegetation on the oceanic carbon cycle. Biogeosciences 2: 1-8.

Duarte, C.M., Merino, M., Agawin, N.S.R., Uri, J., Fortes, M.D., Gallegos, M.E., Marbà, N. \& Hemminga, M.A. 1998. Root production and below ground seagrass biomass. Marine Ecology Progress Series 171: 97-108.

Fourqurean, J.W., Duarte, C.M., Kennedy, H., Marbà, N., Holmer, M., Mateo, M.A., Apostolaki, E.T., Kendrick, G.A., KrauseJensen, D., McGlathery, K.J. \& Serrano, O. 2012a. Seagrass ecosystems as a globally significant carbon stock. Nature Geoscience 5: 505-509.

Fourqurean, J.W., Kenedrick, G.A., Collins, L.S., Chambers, R.M. \& Vaderklift, M.A. 2012b. Carbon, nitrogen and phosphorus storage in subtropical seagrass meadows: Examples from Florida Bay and Shark Bay. Marine and Freshwater Research 63: 967-983.

Kaewsrikhaw, R., Ritchie, R.J. \& Prathep, A. 2016. Variations of tidal exposures and seasons on growth, morphology, anatomy and physiology of the seagrass Halophila ovalis (R.Br.) Hook.f.in a seagass bed in Trang Province, Southern Thailand. Aquatic Botany 130: 11-20.

Lavery, P.S., Mateo, M.A., Serrano, O. \& Rozaimi, M. 2013. Variability of the carbon storage of searass habitats and its implications for global estimates of blue carbon ecosystem service. PLOS ONE 8(9): e73748.

Macreadie, P.I., Baird, M.E., Trevanthan-Tackett, S.M., Larkum, A.W.D. \& Ralph, P.J. 2014. Quantifying and modeling the carbon seqestration capacity of seagrass meadows - A critical assessment. Marine Pollution Bulletin 83: 430-439.

Marbà, N., Arias-Oritz, A., Masque, P., Kendrick, G.A., Mazarrasa, I., Bastyan, G.R., Garcia-Orellana, J. \& Duarte, C.M. 2015. Impact of seagrass loss and subsequent revegetation on carbon sequestration and stock. Journal of Ecology 103: 296-302.

Marbà, N., Duarte, C.M., Terrados, J., Halun, Z., Gacia, E. \& Fortes, M.D. 2010. Effects of seagrass rhizospheres on 
seadiment redox conditions in SE Asian coastal ecosystems. Estuaries and Coasts 33(1): 107-117.

Mcleod, E., Chmura, G.L., Bouillon, S., Salm, R., Bjork, M., Duarte, C.M., Lovelock, C.E., Schlesinger, W.H. \& Siliman, B.R. 2011. A blueprint for blue carbon: Toward and improved undersanding of the role of vegetated coastal habitats in sequestring $\mathrm{CO} 2$. Frontiers in Ecology and Environment 9(10): 552-560.

Pendleton, L., Donato, D.C., Murray, B.C., Crooks, S., Jenkins, W.A., Sifleet, S., Craft, C., Fourqurean, J.W., Kauffman, J.B., Marbà, N., Megonigal, P., Pidgeon, E., Herr, D., Gordon, D. \& Baldera, A. 2012. Estimating global "Blue carbon" emssions from conversion and degradation of vegetated coastal ecosystems. PLoS ONE 7(9): e43542.

Phang, V.X.H., Chou, L.M. \& Friess, D. 2015. Ecosystem carbon stock across a tropical interdial habitat mosaic of mangrove forest, seagrass meadow, mudflat and sandbar. Earth Surgace Process Landforms 40: 1387-1400.

Poovachinranon, S. \& Chasang, H. 1994. Community structure and biomass of seagrass beds in the Andaman Sea. I. Mangrove-associated seagrass beds. Phuket Marine Biologucal Center Research Bulletin 59: 53-64.

Prathep, A. 2012. Seagrass Bed as a Carbon Sink in Ranong Biosphere Reserve and Trang - Haad Chao Mai National Park; An Important Role of Seagrass. Man and Biosphere (MAB) Program, UNESCO.

Prathep, A., Rattanachot, E. \& Tuntiprapas, P. 2010. Seasonal variations in seagrass precentage cover and biomass at Koh Tha Rai, Nakhon Si Thammarat province, Gulf of Thailand. Sonklanakarin Journal of Science and Technology 32(5): 497.

Rattanachot, E. \& Prathep, A. 2015. Species specific effects of three morpholically different below ground seagrasses on sediment properties. Estuarine, Coastal and Shelf Science 167: 427-435.

Rattanachot, E. \& Prathep, A. 2011. Temporal variation in growth and reporduction of Enhalus acoroides (L.f) Royle in a monospecific meadow in Haad Chao Mai National Park, Trang Province, Thailand. Botanica Marina 54: 201-207.

Rozaimi, M., Lavery, P.S., Serrano, O. \& Kyrwood, D. 2016. Long-term carbon storage and its recent loss in an estuarine Posidonia australis meadow (Albany, Western Australia). Estuarine, Coastal and Shelf Science 171: 58-65.
RStudio Team. 2015. $R$ Studio: Integrated Development for $R$. Boston, MA: RStudio Inc. http://www.rstudio.com/.

Supriadi, S., Kaswadji, R.F., Bengen, D.G. \& Hutomo, M. 2014. Carbon stock of seagrass community in Barranglompo Island, Makassar. Ilmu Kelautan 19: 1-10.

Vermaat, J.E., Agawin, N.S.R., Duarte, C.M., Fortes, M.D., Marbà, N. \& Uri, J.S. 1995. Meadow maintenance, growth and productivity of mized Philippine seagrass bed. Marine Ecology Progress Series 124: 215-225.

Vichkovitten, T. 1998. Biomass, growth and productivity of seagrass; Enhalus acoroides (Linn.f) in Khug Kraben Bay, Chanthaburi, Thailand. Kasetsart Journal: Natural Science 32: 109-115.

Milica Stankovic*, Janmanee Panyawai \& Anchana Prathep Seaweed and Seagrass Research Unit Department of Biology Faculty of Science

Prince of Songkla University

90110 Hat Yai

Thailand

Kamarudin Jansanit

Marine and Coastal Resources Research and Development Center The Andaman Coast

Thailand

Tipamat Upanoi

Marine and Coastal Resources Research and Development Center The Middle Gulf of Thailand

Thailand

*Corresponding author; email: svesemenja@gmail.com

Received: 31 August 2016

Accepted: 17 January 2017 